\title{
THE THEORY OF FUNCTIONALISM AND THE INTERNATIONAL CIVIL AVIATION ORGANIZATION (ICAO): AN ANALYTICAL ASSESSMENT AFTER THE FIRST FIFTY YEARS
}

\author{
Isaac Richmond Nettey \\ Texas Southern University
}

\begin{abstract}
The search for world peace has enjoyed perennial attention among scholars and world leaders throughout the ages. Closely allied with the search for world peace is an equally tenacious quest for order, peace and stability in international society. Integrationist theories which postulate the ultimate unification of world communities as a path to world peace constitute one avenue developed by statesmen and political scientists with an interest in world peace. Chief among integrationist theories is the theory of functionalism which gained appreciable currency in the aftermath of World War I. "Classical functionalism relies upon the cooperative pursuit of common interests in nonpolitical fields to generate political changes conducive to peace" (Claude 1956, p. 405).

Fundamental to the theory of functionalism were the seminal writings of David Mitrany $(1933,1943)$, who contended that with the increase in technological sophistication and the need for systemic solutions to complex problems which transcend national borders, people will ultimately transfer their allegiance from nation states to effective international agencies with functional missions which involve the development of international economic and social cooperation. The ample parameters of functional missions include such specific goals as the eradication of poverty, diseases, illiteracy, economic insecurity, exploitation, as well as the elevation of living standards through reductions in the interference caused by national frontiers in an interdependent global economy and improvements in international air travel and commerce.

Functionalism therefore constitutes an important theoretical bedrock for several intergovernmental organizations (IGOs) established to fulfill functional responsibilities in the first half of the twentieth century. Among the IGOs with functional responsibilities is the International Civil Aviation Organization (ICAO) which was formed by 52 nations during the Chicago Conference of 1944. ICAO was formed with the functional mission of ensuring the development of international civil aviation in a safe and orderly manner. As ICAO moves beyond its first half century, it is prudent to conclude that international civil aviation is quite safe and very orderly. After a careful narrative analyses of the theory of functionalism and $I C A O$, this paper concludes that the jury may still be out on whether functionalist predictions will ever be validated by a transfer of allegiance from nation states to a functional IGO such as ICAO.
\end{abstract}

\section{Introduction}

The carnage of World War I, and a certain optimistic belief that wars could be eradicated by integrating the peoples of the World, gave considerable impetus to integrationist political theories after World War I. Integrationist theories are primarily concerned with promoting world peace through the integration of political communities. Of all the political 
communities who exert an impact on the world stage, nation states through their respective national governments, constitute the primary actors in international affairs. As such, nation states as unit and rational actors, receive considerable emphasis in integrationist theories.

Critical to the broader subject of integrating political communities are the fundamental political questions of why citizens give allegiance to a nation state and how political systems, especially the nation state, remains cohesive. Nation states are of particular importance in this discussion primarily because they have become the dominant unit actor in international politics since their inception at the Treaty of Westphalia in 1648 and subsequent validation at the Congress of Vienna in 1815 (Bull, 1977). In addition, political scientists concerned with integrationist policies focus considerable attention on the role of nation states in international conflict.

The first of two reigning schools of thought traces the locus of cohesion within political systems to consensus - widely shared values among a political system's citizens and general agreement about the structure and function of the political system. Consensus in this context is akin to Kissinger's (1964) concept of legitimacy. Consensus among citizenry and its governing entity is the locus of some legitimacy for a regime. In scholarly work closely related to this issue, Reinhold Niebuhr (1949) and Hans Morgenthau (1962) have successfully argued that world government is simply not possible without greater consensus at the global level.

The second school of thought on cohesion within political systems primarily advocates the presence of coercive force, or the threat of force, as an indispensable prerequisite for cohesion within a political system. Thomas Hobbes (1967) and Ralf Dahrendorf $(1959,1968)$ could be placed within the second of the two schools of thought. A careful examination of the two schools of thought indicates that they are not necessarily mutually exclusive since coercion may have an interactive effect on the development and maintenance of consensus in a political system.

Dominant among integrationist theories is the concept of functionalism. Functionalism is not only dominant among integrationist theories, it is perhaps one of the earliest forms of integrationist theories. Indeed, functionalism as a political theory, may be responsible for spawning similar theoretical concepts of political integration. Within the confines of political science and international relations, integrationist concepts similar to functionalism that have enjoyed theoretical currency may include regionalism, alliance cohesion, sector integration and neo-functionalism.

A theoretical analyses of the theory of functionalism and the work of the International Civil Aviation Organization (ICAO) after its first half century shall remain the subject of this paper. The paper initially discusses the theory of functionalism and then explores the viability of functionalism as a practical concept in international politics through the work of ICAO. This paper analyzes the theory of functionalism primarily because the larger question of world peace still remains a salient issue of critical importance to the continued existence of international society. For both professionals and scholars involved in international politics or aviation, ICAO may represent one of a limited number of important examples of a successful functional intergovernmental agency (IGO) on the world stage 


\section{Functionalism}

\section{Conceptual Origin}

Functionalism as a political theory in IR may owe its name and meaning to the fact that the "functional" sector of international organizations generally refers to activities related to the promotion of human welfare. Activities directed towards promoting human welfare on a global scale include technical, economical, social, humanitarian and social justice issues directed towards improving the quality of life vis a vis the prevention of war or the elimination of national insecurity (Claude, 1971).

International politics prior to the end of World War I focused almost exclusively on national security issues and the prevention of war. International summitry and diplomacy prior to the nineteenth century seldom, if ever, focused on social welfare issues. Social welfare issues were primarily viewed as intrastate issues which fell strictly under the jurisdictions of respective sovereign nations. The concept of functionalism has provided an alternative to the traditional legal conceptions of the nation state and of sovereignty (DeVree, 1972, Dougherty and Pfaltzgraff , 1994).

\section{Mitrany's Functionalism}

Functionalism as an IR theory came into being largely as a result of the professional and scholarly work of the British civil servant, David Mitrany. Writing between World Wars I and II, and in the post war years, Mitrany postulated that "the problem of our time is not how to keep the nations peacefully apart but how to bring them actively together" (Mitrany, $1966 \mathrm{p}$. 28 ). Without tackling the issue of peace directly, Mitrany advocated the development of special purpose organizations which will fulfill important needs of the world's citizens directly $(1933,1966)$. Such needs include elevation of living standards, reduction or elimination of illiteracy, ill-health, economic insecurity, social injustice, exploitation and discrimination.

Through direct fulfillment of social needs at the global level, special purpose organizations will succeed in "linking authority to a specific activity, ... and in the process breaking away from the traditional link between authority and a definite territory" (Mitrany, 1966 p. 27). Through this approach, the activities of international agencies would encourage a shift in the allegiance of the World's citizens from their respective sovereign nations to international special purpose organizations. As stated by Mitrany (1966) in A Working Peace System:

Sovereignty cannot in fact be transferred effectively through a formula, only through a function. By entrusting an authority with a certain task, carrying with it command over the requisite powers and means, a slice of sovereignty is transferred from the old authority to the new; and the accumulation of such partial transfers in time brings about a translation of the true seat of authority. (p. 31)

Creation of transnational allegiances to supranational political entities will ultimately result in defacto integration of nations which Mitrany calls "federalism by installments" (1966, $p$. 83). Functionalism would thus "overlay political divisions with a spreading web of international activities and agencies, in which and through which, the interests and life of all the nations would be gradually integrated (Mitrany, 1966). 
Integration of nations through functional activities would thus result in a significant diminution, if not outright elimination, of the need for war. In other words, if the nations of the World are fully integrated and functionally engaged in productive activities to improve life for all persons, there shall be neither the need nor rationale for such destructive enterprises as interstate war. The ultimate elimination of war through gradual integration of nations is felicitously characterized as "peace by pieces." (Schuman, n.d.) In addition to the ultimate prevention of war, Mitrany also believed the activities of special purpose international agencies would lead to the "development of authoritative world political institutions" (Claude, $1971 \mathrm{p}$. 380)

Underlining Mitrany's concept of functionalism was the belief that increases in the complexity of technical and noripolitical challenges facing governments in the twentieth century have created a demand for technical specialists and an international approach to solving problems. Problems related to health care and halting the transnational spread of deadly pathogens as well as, complex technological problems caused by growth in global transportation and communication, made a collaborationist approach to solving global problems mandatory. In a major departure from historical practice in relations between sovereign nations, the main units engaged in collaborationist efforts to solve the World's problems under functionalist theory will be technical specialists, not political elites. Collaborationist efforts under functionalism involve technical specialists who work within an international framework of technical cooperation which transcends sovereign nations. Unlike the political elites who had dominated international relations in the past, the technical specialists under functionalism can be expected to be apolitical technocrats who will focus on technical issues and not remain preoccupied with power politics which has historically led to war.

\section{Functionalism and Ramification}

Functionalism predicted the proliferation of international frameworks for technical cooperation as technological developments become more complex and widespread in application throughout the world. The predicted proliferation of international frameworks for technical cooperation is congruent with Mitrany's doctrine of ramification. Ramification asserts that collaboration in one technical field has a multiplier effect which manifests itself in additional collaborationist efforts in other technical fields at the global level. Preceding Mitrany's writings on functionalism and ramification was Paul S. Reinsch who postulated a similar doctrine under the concept of "concentric circles of cooperation" which will emanate from the limited area of technical agencies to solve other global problems of a political nature (1911). In additional work on ramification, Paul $\mathrm{G}$. Hoffman also contended that when habits of unity are cultivated in the economic sphere, they naturally spread over to the political sphere and even to the military sphere when the need arises (1951, p. 62). Somewhat akin to Mitrany's ramification is the concept of spill-over. Developed as a result of analytical studies of the European Coal and Steel Community (ECSC) by Ernst Haas, the concept of "spill-over" generally refers to the tendency of persons who have benefitted from the collaborationist efforts of supranational institutions in one functional area to advocate and support integration in other areas (1964, p. 48). Eventually, collaborationist efforts which are cooperative in nature absorb the political sector. In this respect, functionalism regards cooperation, instead of competition and conflict, as the dominant behavioral paradigm in international relations. Functionalism can therefore be envisaged as a theory which is "peace oriented and seeks to 
avoid a win-lose stalemate framework" (Groom \& Taylor n.d.). In effect, functionalism represents a fairly radical departure from the international relations concept of realism ${ }^{1}$. As contrasted with the concept of realism, functionalism may be more normative than descriptive of international politics.

Directly descending from functionalism, is the more recent concept of neofunctionalism which has modified functionalism through testing of hypothesis with a special, if not exclusive, emphasis on the European Community. Leading proponents of neofunctionalism include Ernst Haas, Robert Keohane, Leon Lindbergh, Joseph Nye, Lawrence Scheineman and Phillipe Schmitter. The scope of this paper will not permit a thorough discussion of neofunctionalism as a modification of the integrationist theory of functionalism.

\section{Functionalism in the Post World War I Era}

Prevention of war enjoys perennial attention. Concern about the prevention of war, especially interstate war, significantly heightened after World War I. In the post World War I atmosphere of deep concern about preventing interstate war, functionalism enjoyed considerable currency among the political elite in Western nations. Proponents of functionalism touted their belief that "the development of international economic and social cooperation is a major prerequisite for the ultimate solution of political conflicts and elimination of war" (Claude, 1971 p. 379).

In the post World War I era, there was extensive belief in functionalism's claim that the need for nation states to jealously guard their respective sovereignties inexorably leads to war between their respectively carved pieces of the world. Worse yet, both the socioeconomic and technological development of the world was presenting challenges which transcend the capabilities of individual nation states. Solutions to such challenges could only come from an international group of experts who work under the umbrella of a supranational functional organization. Solutions to global problems and challenges lie with "problem solving agencies coterminous in territorial competence with the problem areas" (Claude, 1962 p. 382), not fragmented groups artificially segregated by the equally artificial borders of their respective nations states.

Faith in the preceding proposition caused the germination of several policies and practices in international politics which were firmly grounded in functionalism. Functionalism as a theory therefore enjoyed operational and practical implementation through the establishment of several international organizations in the aftermath of World War I. Chief among the post World War I international organizations were the League of Nations and the International Labour Organization (ILO). The League of Nations, originally a "nonfunctionalist" organization, overwhelmingly emphasized political matters in a deliberate attempt to exclude nonpolitical matters. Pressure from Great Britain and General Smutts ${ }^{2}$ prevailed in securing the inclusion of Articles 23-25 in the League's Covenant, thus allowing cursory involvement in

${ }^{1}$ Realism, a dominant political theory governing US foreign policy and international relations since World War II, postulates that conflict and competition, not cooperation, are the dominant paradigms in international politics

${ }^{2}$ General Jan Smutts of South Africa was instrumental in founding the RAF, and by proxy, the USAF through his influence on Billy Mitchell, his aide de camp in the early years of World War II 
functional issues. Unlike the League of Nations, ILO was the international entity primarily tasked with responsibilities of a functional nature in the post World War I era (Claude, 1971).

Notwithstanding the limited emphasis on functionalist responsibilities in its charter, the League emerged as an international organization with major functional emphasis and established several technical organizations for international assistance, sponsored international conferences and served as a forum for stimulating and coordinating multilateral efforts to cope with complex modern economic and social problems (League of Nations, 1938). The League might have turned its attention to functionalism either because its efforts in political matters were a rum affair, or it needed to find new uses for its administrative machinery. The most enduring legacy of the League were probably, the accomplishments of its functional agencies and its successful demonstration of the potential for international cooperation and collaboration in areas remote from the issue of power politics (Claude, 1962 p. 392).

Success of the League's functional agencies significantly contributed towards the establishment of a battery of functional institutions as Specialized Agencies of its progeny; the United Nations (UN). Among the Specialized Agencies adjunct to the UN were the ILO, Food and Agricultural Organization (FAO), United Nations Educational, Scientific and Cultural Organization (UNESCO), International Civil Aviation Organization (ICAO), International Bank for Reconstruction and Development (IBRD), International Monetary Fund (IMF), International Finance Corporation, International Development Association, World Health Organization (WHO), Universal Postal Union, International Telecommunications Union (ITU), World Meteorological Organization (WMO), and Inter-governmental Maritime Consultative Organization. In addition to the preceding list is the International Atomic Energy Agency (AEA) which has a distinctive formal status but may be considered as a quasi Specialized Agency group. It may be appropriate to indicate that several of the Specialized Agencies, such as the ILO and ICAO, were established before the UN was established.

American initiative is credited with the ambitiousness of the scope of the UN's Specialized Agencies and the decentralized character of its administrative pattern (Stettinius, 1949). It is somewhat paradoxical that although United States foreign policy does not enthusiastically subscribe to functionalism, it turned out to be the main supporter of the functionalist enterprises of the newly chartered UN. US support for the UN's functional agencies may be explained by the fortuitous coincidence of America's conception of an effective halt to the spread of communism with the functionalist conception of how best to build the foundations of a peaceful society (Claude, 1968). In reviewing the breadth of the functionalist thrust of the newly chartered UN, it has been rightly contended that "... never in the history of mankind has an attack on the first causes of war been launched on so many fronts and with the mobilization of comparable scientific resources "(Martin, 1952, p. 22)

Over the last five decades of its existence, the actual work of the UN has primarily revolved around helping nations and fostering intergovernmental assistance between nations through fact finding, research, sponsorship of consultation on an international scale, and standardization or harmonization of national programs and policies. It is primarily in the functional area of standardization of national programs and policies that ICAO has thrived. The remainder of this paper will discuss the function of ICAO in an analytical attempt to determine the effectiveness or success of functionalism as an international relations concept or paradigm. 


\section{International Civil Aviation Organization}

As is typical of its sister Specialized Agencies, and other IGOs at the UN, ICAO is a technical body. Unlike its sister Specialized Agencies, ICAO deals with a relatively new phenomenon, commercial air transportation. Growth in commercial air travel has ensured its rapid rise as the preferred mode of transportation for journeys exceeding 200 miles in the United States and journeys exceeding a thousand miles around the world. That this feat occurred in less than half a century after commercial air transportation began, is a wonder! Even more incredible, is the realization that this feat is unparalleled in the history of transportation which spans several millennia. Within fifty years of its introduction, commercial air transportation successfully developed to the point where it could "carry man and his goods anywhere and everywhere without fetter and without halt" on Earth (Facts About ICAO, 1994).

Of some considerable importance is the fact that the phenomenal growth of commercial air transportation has been adventurous, yet remarkably orderly. Today, a flight can regularly depart from New York, with an appreciable degree of confidence, that after a series of requisite stops for fuel and other logistical supplies, it would make it to Timbuktu in Mali, and return to New York, if necessary, before the day is over. In Timbuktu, the flight would execute approach procedures quite similar to what it would in Chicago. Such orderliness and harmony in international affairs is neither accidental nor ordinary. Much of the credit for the harmonious growth and operation of commercial air transportation, especially international air travel, could be ascribed to functionalist cooperation between nations through summitry for functional purposes and collaborative work on an international scale. Functionalism, in the form of intergovernmental summitry and international collaboration, were instrumental in the formation of ICAO.

ICAO was formed to fulfill quite a specific and somewhat limited set of functions which has not altered significantly since its formation. The governing philosophy of ICAO, as spelled out in the preamble to the Convention on International Civil Aviation (Chicago, December 7 , 1944 ) below, is very functionalist in orientation:

Whereas the future development of international civil aviation can greatly help to create and preserve friendship and understanding among the nations and peoples of the World, yet its abuse can become a threat to the general security; and Whereas it is desirable to avoid friction and to promote that cooperation between nations and peoples upon which the peace of the World depends; Therefore, the undersigned governments having agreed on certain principles and arrangements in order that international civil aviation may be developed in a safe and orderly manner and that international air transport services may be established on the basis of equality of opportunity and operated soundly and economically; Have accordingly concluded this Convention to that end.

\section{Historical Origin}

Technological developments during war have always expedited improvements in aeronautical technology. At the end of World War I, the first international summit on aviation the Paris Convention, was held in 1918 to develop the rudiments of international air law. The main issues of concern revolved around the concept of sovereignty over territorial airspace and protocols for international air travel, as well as subordinate issues of comity in crew and equipment licensure. Participation was limited to a few European nations who had managed 
to develop comparably limited networks of commercial air transportation service by 1918 . Much of the preparatory work for the Paris Convention was patterned after maritime law partly because most European colonial powers had historically subscribed to Sir Walter Raleigh's dictum:

Whosoever commands the sea, commands the trade; whosoever commands the trade of the world commands the riches of the world, and consequently the world itself.

Recognition of the potential wealth, through trade, offered by the fledgling mode of transportation was not lost on the delegates at the Paris Convention. To consolidate their gains, the International Commission on Air Navigation (ICAN) was established in Paris in 1919 (Mance, 1944, Van Zandt, 1945). ICAN was limited in scope and so it functioned as a limited technical body over a relatively short period.

The second World War "telescoped a quarter-century of normal peace-time technical developments in aviation into six years" (Memorandum on ICAO, 1994 p. 8). Anticipation of a significant growth in demand for commercial air service at the end of World War II, and an appreciable degree of conviction in a functionalist approach to international relations, led the allied nations of Canada, Great Britain and the United States to convene the Conference on International Civil Aviation, a.k.a. The Chicago Conference. Fifty-two of the 55 nations invited to the conference, excluding the Soviet Union, sent delegates to Chicago in November, 1944. After five weeks of deliberations, the delegates were successful in developing the previously stated preamble, Convention on International Civil Aviation which was signed on December 7 , 1944 (Memorandum on ICAO,1994). In addition to the preamble, delegates to the Chicago Conference also established a protocol or convention, known as the Chicago Convention, and an administrative agency tasked with responsibilities for implementation of the Chicago Convention. The Chicago Convention came into force on April 4, 1947, thirty days after its ratification by the 26th contracting state. The Provisional International Civil Aviation Organization (PICAO), formed with advisory powers only, administered the Convention before its ratification. PICAO therefore functioned for 20 months during which it successfully garnered 50 contracting states before it was formally replaced by ICAO on April 4, 1947 (Memorandum on ICAO, 1994).

During the Conference on International Civil Aviation, opinions on the structure of post war civil aviation and the authority of ICAO varied considerably. Working in concert with each other, Australia and New Zealand proposed international ownership and control of global trunk routes. ${ }^{3}$ The United States championed an "open skies" regimen in international air carrier service and free competition among air carriers. Great Britain advocated orderly and controlled development of international air carrier service. In the absence of compromise between Great Britain and the United States, the conference could not establish a strong regulatory body. Instead, it established a limited technical body tasked primarily with standardizing operations and the technical development of international civil aviation (Kihl, 1971).

\footnotetext{
${ }^{3}$ Trunk routes referred to long distance routes between large cities or major population centers.
} 


\section{The Chicago Convention of 1944}

The Chicago Convention comprises 96 articles designed to; "develop the principles and techniques of international air navigation and to foster the planning and development of international air transport" (Memorandum on ICAO, p. 1966); establish the privileges and restrictions of all member states; provide for the adoption of International Standards and Recommended Practices (SARPS) to regulate air navigation and facilitate air transportation by fulfilling tasks necessary to "meet the needs of the peoples of the world for safe, regular, efficient and economic air transport, encourage the arts of aircraft design and operation for peaceful purposes, encourage the development of airways, airports, and air navigation facilities for international civil aviation, prevent economic waste caused by unreasonable competition and avoid discrimination between Contracting States" (Memorandum on ICAO, 1996, p.13).

An issue of considerable importance at the Chicago Conference pertained to the exchange of commercial rights in international air service. Divergent opinions on this subject rendered a satisfactory solution impossible. A workable compromise was however finessed through two agreements, namely; the International Air Services Transit Agreement (a.k.a. Two-Freedoms or Transit Agreement) and the International Air Transport Agreement (a.k.a. Five-Freedoms or Air Transport Agreement). The Two-Freedoms agreement which called for the right of transit over foreign territory and the right to land in foreign territory for non commercial purposes enjoyed wider acceptance than the Five-Freedoms agreement which called for the right of commercial service between signatory states. By December 1992, a hundred nations had signed on to the Two-Freedoms agreement and only eleven had accepted the more commercially extensive Five-Freedoms agreement (Memorandum on ICAO 1994).

Failure of the Chicago Convention to secure wider acceptance for both Agreements was a fairly significant setback for the rather lofty functionalist aspirations of the Conference. Rejection of the Air Transport Agreement implied that international air service between each set of two nations would have to be carried out under the terms of bilateral agreements between respective nations, instead of the anticipated global multilateral agreement applicable to all contracting nations. Today, bilateral agreements completely govern the international arena of air transportation and multilateral agreements remain a rarity (The Convention on International Civil Aviation, 1991).

Over the years, ICAO has successfully developed and adopted 18 technical Annexes to the Chicago Convention which deal with aeronautical communications, air navigation, air worthiness, environmental protection and security, meteorology and operations. Of the 18 technical Annexes, 17 are within the air navigation field (Memorandum on ICAO,1994). Implementation of these Annexes through SARPs has successfully produced an appreciable degree of technical uniformity which has fostered safety and efficiency in international aviation. The Annexes and their SARPs serve as ICAO's main administrative tools. Failing to secure the sweeping mandate to govern international aviation that it had originally anticipated at the Chicago Conference, ICAO has successfully managed to evolve into a fairly effective technical body promoting intergovernmental cooperation in international civil aviation. 


\section{ICAO's Operational Structure and Function}

At the invitation of Canada, ICAO established its headquarters in Montreal. ICAO however maintains regional offices in Bangkok, Cairo, Dakar, Lima, Mexico City, Nairobi and Paris. Issues of a regional nature, are generally addressed in a customized fashion by each of the nine regions of ICAO. Within the nine regions are 183 contracting nations (as of 2/20/94), a significant increase from 41 members on July 1,1947 . The sovereign body of ICAO is an Assembly of all contracting nations which meets at least once every three years as convened by the Council. The Assembly democratically adopts policies, binding standards and procedures, sets directional guidelines for the entire organization and elects representatives from 33 contracting nations ${ }^{4}$ to serve three year terms on ICAO's Council which is in permanent session. The Council governs all functions of ICAO under the leadership of a president. $^{5}$ The permanent Council exercises oversight over four additional organs of ICAO, namely; the Air Navigation Commission, Air Transport Committee, the Committee on Joint Support of Air Navigation Services and the Finance Committee.

A major responsibility of the Council involves recommendation of SARPs and subsequent incorporation as Annexes into the Convention on International Civil Aviation. The Council may also serve as an arbiter between member states on issues pertaining to international air service or implementation of organization policies. Through its headquarters facilities, the Council convenes several professional meetings on aviation and serves as a forum for interaction between policy makers and international experts on different aspects of aviation. Participating in ICAO meetings are representatives and experts from other specialized agencies of the UN such as ITU, UPU and WMO as well as nongovernmental organizations (NGOs) including Airports Council International (ACI), American Association of Airport Executives (AAAE) and Airline Pilots Association (ALPA). In addition to the SARPs, ICAO also formulates Procedures for Air Navigation Services or PANS (operating practices with detailed information) which amplify the SARPs for implementation purposes. To facilitate effective implementation of SARPs at the regional level, ICAO develops Regional Supplementary Procedures (SUPPS) for adoption and implementation on a regional basis. After standards are adopted by ICAO, they are put into effect by each contracting state.

Assisting the Council in its work is a Secretariat which could be divided into the three areas of; professional personnel, language staff personnel and clerical or support staff personnel. Most employees of the Secretariat are nationals of contracting states with fairly extensive commercial air transportation services such as Great Britain, France, Canada and the U.S.

Notwithstanding its highly technical focus and mission, ICAO's functions are not apolitical as would be expected under functionalism. Political conflict emerges when there is a clash of economic and national interests among nations (Kihl, 1971). Absence of the Soviet

${ }^{4}$ The original number of Council Member States was 21; this number was increased to 27 through an amendment in 1962, and to 30 in 1973. The number of Council members was increased to 33 in 1980 at the 21 st Session of the Assembly held in Montreal in Sept.- Oct., 1974. In October, 1990 the 28th Session (Extraordinary) adopted an amendment to increase the number of Council members to 36 . This amendment is not yet in force.

${ }^{5}$ Edward Warner, professor of aeronautics at MIT, and the first person to hold the Council's presidency, was successful in competently sheparding the Council through its nascent years. 
Union throughout most of ICAO's life has spared it the political gridlock which paralyzed most UN action till the end of the cold war. In spite of the absence of insurmountable ideological differences, ICAO faces several conflicts among the competing interests of several actors. As a functional organization, ICAO however manages to serve both as an "arena for conflict and as a workshop for collaboration" by constant "attempts to minimize the conflictual and maximize the cooperative aspects of international relations" (Claude, 1964 p. 14). That ICAO has enjoyed success may be beyond debate. International air travel continues to flourish as is demonstrated in the following chart (Table 1) of passengers carried in the ten year period between 1984 and 1993.

Table 1

Global Passenger Count (millions) and Freight (Tonnes) Each Year: 1984-1993

\begin{tabular}{|c|c|c|c|c|c|}
\hline Year & $\begin{array}{c}\text { Passenger } \\
\text { Count }\end{array}$ & $\begin{array}{c}\text { Total Freight } \\
\text { in Tonnes }\end{array}$ & $\begin{array}{c}\text { Passenger } \\
\text { Load Factor }\end{array}$ & $\begin{array}{c}\text { International } \\
\text { Passengers }\end{array}$ & $\begin{array}{c}\text { International } \\
\text { Freight }\end{array}$ \\
\hline 1984 & 848 & 13.4 & $65 \%$ & 185 & 5.8 \\
\hline 1985 & 899 & 13.7 & $66 \%$ & 194 & 5.9 \\
\hline 1986 & 960 & 14.7 & $65 \%$ & 198 & 6.4 \\
\hline 1987 & 1,028 & 16.1 & $67 \%$ & 222 & 7.2 \\
\hline 1988 & 1,082 & 17.2 & $68 \%$ & 243 & 7.8 \\
\hline 1989 & 1,119 & 18.2 & $68 \%$ & 262 & 8.6 \\
\hline 1990 & 1,165 & 18.3 & $68 \%$ & 280 & 8.9 \\
\hline 1991 & 1,134 & 17.4 & $66 \%$ & 266 & 8.5 \\
\hline 1992 & 1,156 & 17.3 & $66 \%$ & 299 & 9.3 \\
\hline 1993 (est.) & 1,166 & 17.5 & $66 \%$ & 317 & 9.7 \\
\hline
\end{tabular}

Source: ICAO (December, 1993) quoted in Memorandum on ICAO 1994 pp. 38,39

\section{Functionalism's Failures and ICAO}

The experience of ICAO may suggest that the fundamental assumptions of functionalism may be theoretically plausible but its practicality may, however, be doubtful, if not dubious. Among the assumptions of functionalism is the premise, or belief, that human affairs can be neatly stratified into layers, thus socioeconomic problems can be neatly dissected from political problems. The experience of ICAO has shown that the socio economic interests of contracting nations evolve into adamant political positions on issues before ICAO (Kihl, 1971). The higher the stakes involved in a dispute over socioeconomic issues the more complete the metamorphosis of socioeconomic issues into political positions at ICAO. Other scholars have contended that "the artificial dissection of organic economic ties into separate economic organizations under independent authorities endangers viability" (Bebr, 1953 p. 42). 
As previously stated, functionalism's canon of transferability assumes that cooperative skills acquired through collaborative work on technical issues under the auspices of functional agencies can be transferred to develop collaborative solutions at the highest political levels (Claude, 1971). This expectation is achievable and sound under altruistic circumstances. Altruistic circumstances however tend to be the exception than the rule in politics, especially political interaction between state actors at the international level. National self-interest tends to subsume altruistic behaviour among state actors primarily because the ultimate responsibility of state actors is the security of their respective subnational constituencies. Pursuit of the security interests of state actors always has the potential of colliding with similar pursuits by other states. The political positions held by the Allied nations who formed ICAO were clearly the result of attempts to respond to the parochial interests of each contracting state's citizenry. When these interests collided, ICAO took refuge as a technical body with limited responsibilities instead of a powerful IGO with broad regulatory authority to govern the international air transportation system.

Of the hypotheses espoused by functionalism, the most radical is the assumption that human loyalties will be transferred from the nation state to transnational functional agencies as the efficacy and effectiveness of those agencies become evident. It is not wrong to assume an increase in allegiance to effective functional agencies. Judging by the level of participation in its activities, ICAO's successes have won it allegiance among the ranks of the international air transportation community. It may however be inaccurate to assume or expect the increase in allegiance to be either permanent, or at the expense of nation states. Among the several contentious issues in the life of ICAO that soundly confirm this assertion, one warrants narration in this paper to substantiate this point

In response to an increase in trans Atlantic traffic, from 90 propeller-driven airplanes a day in 1956, to 220 airplanes (85\% of which were jets) a day in 1966, ICAO reduced the required lateral separation between aircraft from 120 miles to 90 miles, effective January 13 , 1966. The change was to affect transoceanic air corridors which begin about a 100 miles from shore and end a similar distance from shore. With US support, this measure passed the ICAO Council with a vote of 18 to 0 and 4 abstentions. ${ }^{6}$ An NGO, the International Federation of Airline Pilots Associations (IFALPA) vigorously opposed the rule imposed by ICAO- an IGO, and requested that ICAO suspend the new rule till further studies were completed (New York Times 1/9/66). ICAO naturally refused but was ultimately compelled to abandon the new rule primarily because of pressure from the US Government through the FAA on behalf of ALPA, the domestic counterpart of IFALPA. So whereas ALPA had championed other ICAO decisions in the past, it did not hesitate to turn to its national government when it was in ALPA's perceived interest to do so. Despite its initial vote for the new rule, the US government did not hesitate to switch sides on this issue when the loyalty of its citizenry was at stake.

Recent events in international politics suggest that, in the logical interest of self preservation, nation states would not idly watch as support for their governments gets transferred to functionalist international entities. Recent events in Somalia constitute a tragic, yet prime example. In an environment where the quasi governmental entities, the clans, could

\footnotetext{
${ }^{6}$ The member states who abstained from this vote were Belgium, India, Spain and Great Britain. The United States cast a firm vote in support of this policy change. At present, the lateral separation for aircraft traffic across the North Atlantic ICAO Region is 60 nautical miles for supersonic aircraft above FL 275 and aircraft which meet the Minimum Navigation Performance Specification (MNPS) Airspace and 90 nautical miles between the U.S., Canada, Bermuda and points in the Caribbean ICAO Region (7110.65J Air Traffic Control 1995 8-7-1).
} 
not provide for the social welfare and survival needs of their kin, they allowed NGOs under the auspices of the United Nations to intervene and assist but they retained their emotional hold on the allegiance of their clansmen who were ironically saved from starvation by the NGOs to later fight for their clans. In an even more powerful commentary on the flaws in functionalism's assumption about the transferability of allegiance, some of the Somali clansmen who were saved from death by starvation, took up arms against the NGOs who had saved them when it was in the political interest of the clans to do so.

\section{Summary and Conclusion}

Functional agencies and alliances are formed for limited purposes and objectives. As such, they last as long as needed to accomplish certain accepted objectives, not to transfer allegiance or sovereignty. ICAO was formed to improve international air transportation services. The need to improve international air transportation services persists fifty years after the Chicago Convention, so ICAO enjoys both a legitimate mandate and appropriate support. As a functional agency which is transnational in structure and function, ICAO will receive the support of several sub-national entities so long as it fulfills its ascribed role in facilitating the development of international air transportation. ICAO will enjoy loyalty and even some allegiance from sub-national entities as it does its work. The loyalty and allegiance from the sub-national entities will however be transient and equally "functional" because ICAO offers neither citizenship nor nationalistic belonging. Allegiance to ICAO is, therefore, dependent upon its continued function as a collective agency for developing international aviation.

If rules are the norms and standards governing the behavior of actors in society, then ICAO has done well because most of the technical standards it develops or stipulates are accepted as rules and implemented by its member states. Future challenges and the escalating demands of its member states will ensure ICAO's continued viability as a functional agency. It would however be a mistake to ascribe to ICAO, or any other functional agency, the status of a nation. In ICAO, there is neither the consensus prescribed by Niebuhr (1949) and Morgenthau (1962), nor coercive force required for cohesion in a political system prescribed by Hobbes (1967) and Dahrendorf $(1959,1968)$. The "link between authority and activity," and the subsequent "breakaway from the traditional link between authority and a definite territory" (Mitrany, 1966 p. 27) has not occurred among the members of ICAO. Neither has sovereignty been transferred through function at ICAO after fifty years of relative success. From the preceding discussion of functionalism and the first fifty years of ICAO, it is clear that functionalism is an apt normative philosophy in the theory of international relations and politics. However, functionalism is neither descriptive, prescriptive, nor representative of the present international political system. There may however still be a remote chance that the next fifty years of ICAO will produce another verdict on the viability of functionalism's predictions.

\section{References}

Air traffic rules and procedures service (1995, July 20). 1710.65J Air Traffic Control Washington, D.C.: DOT Federal Aviation Administration, 8-7-1.

Bull, H. (1977). The anarchical society: A study of order in world politics. New York: Columbia University Press.

Bebr, G. (1953, November). "The European coal and steel community: A political and legal innovation," Yale Law Journal. 
Claude Jr., I. L. (1971). Swords into plowshares: The problems and progress of international organization. New York: Random House.

Claude Jr., I. L.(1962). In power and international relations. New York: Random House.

Cooper, J. C., (1952). International air navigation conference, Paris 1910. Journal of Air Law and Commerce, $19,127-143$.

Dahrendorf, R.(1959). Class and class conflict In industrial society. Stanford: CA:

Stanford University Press.

Dahrendorf, R.(1968). Essays in the theory of society. Stanford: CA: Stanford University Press

De Vree, J. K. (1972). Political integration: The formation of theory and its problems. The Hague-Paris: Mouton.

Dougherty, J. E. \& R. L. Pfaltzgraff, Jr., (1990). Contending theories of international relations: A comprehensive survey. New York: Harper Collins.

Groom, A.J.R. \& Paul Taylor.(n.d.). Functionalism and international relations, in Groom and Taylor, Eds., Theory and Practice in International Relations: Functionalism New York: Crane, Russak, p. 2.

Hass, E. B. (1958). The uniting of Europe. Stanford, CA: Stanford University Press.

Hobbes, T.(1967). Leviathan. Oxford: Basil H. Blackwell.

Hoffman, P. G. (1951). Peace can be won. New York: Doubleday.

ICAO (1994). Facts about ICAO. Montreal: Public Information Service of ICAO.

ICAO (1994, January 15). Memorandum on ICAO: The Story of the International Civil Aviation Organization Montreal, Canada: ICAO.

ICAO (1991, February). The convention on international civil aviation: Annexes 1 to 18, the first 46 years. Montreal, Canada: ICAO.

Kihl, Y. W. (1971). Conflict issues and international civil aviation decisions: Three cases. Monograph Series in World Affairs. Denver, Co.: University of Denver, 1-96.

Kissinger, H. A.(1964). A world restored-Europe after napoleon: The politics of conservatism in a revolutionary age. New York: Grosset and Dunlap.

League of Nations (1938). The aims, methods and activity of the League of Nations, (Rev. ed). Geneva: Secretariat of the League of Nations.

Mance, O. (1994). International air transport.

Martin, A. (1952). Collective security: A progress report. Paris: UNESCO.

Mitrany, D.(1966). A working peace system. Chicago: Quadrangle Books.

Mitrany, D. (1933). The progress of international government. New Haven: Yale University Press.

Morgenthau, H. J. (1962). In power and international relations. New York: Random House.

Niebuhr, R. (1949, October). The illusion of world government. Bulletin of the Atomic Scientists, V. 289-292.

Reinsch, P. S. (1911). Public international unions. Boston: Ginn.

Schuman, F. L. (n.d.). The commonwealth of man.

Stettinius, E. R. (1949). Roosevelt and the Russians. Garden City, NY.: Doubleday

Van Zandt, J. P., (1945). The Chicago civil aviation conference," 21 Foreign Policy Reports, 289-308. 